\title{
Comparing the Law Related to Market Manipulation in Islamic Law and US Law
}

\author{
Saad A. Aljloud ${ }^{1}$ \\ ${ }^{1}$ Department of Fiqh, College of Shariah and Islamic Studies, Qassim University, Buraydah, Saudi Arabia \\ Correspondence: Saad A. Aljloud. E-mail: isaadii@hotmail.com
}

Received: November 27, 2019

Accepted: December 13, 2019

Online Published: December 31, 2019

doi:10.5539/ass.v16n1p80

URL: https://doi.org/10.5539/ass.v16n1p80

\begin{abstract}
The financial markets have been beset by large-scale market manipulations since its beginning. This article focuses on comparing the laws of market manipulation of the US and Islamic law and how Muslim countries get benefits from US regulation of financial markets. This will investigate market manipulation from US law and Islamic perspective. This article will present a comprehensive step review of the Islamic law regarding market manipulation. Also this article begins with a snapshot of financial markets in US law and the meaning of manipulation. Understanding more about the way the jurisprudence was designed to adapt to the existing laws and institutions of the Islamic Shariah will help place some of the unique features in Islamic law of financial markets.

We will discuss the Islamic doctrine hisbah (حسبة) which means 'accountability' or a duty to 'enjoin good and forbid wrong' and how it benefits Islamic financial markets. Finally we will discuss whether principles of market manipulation, supplemented in Islamic law, have attained their purpose.
\end{abstract}

Keywords: Islamic perspective, market manipulation, financial market, regulation

\section{Historical of Manipulations}

There is a long history of trading in commodity futures. ${ }^{1}$ In the US, this history can be traced to the end of the Civil War and, specifically, to the Chicago Board of Trade. Contracts for the supply of grain were changed into movable contracts that were repeatedly used to counterbalance each other. ${ }^{2}$ Speculators quickly gained an understanding that these contracts provided openings for individuals to take part in underhand actions and also to make assumptions. ${ }^{3}$

So-called 'corners' and 'squeezes' gained popularity, and manipulators became viewed as legendary, as demonstrated by the story of Joe Leiter, a former Harvard student who made an unsuccessful attempt to turn the wheat market. His corner was destroyed after ships rented by P. D. Armour manipulation of commodity futures prices made their way through the ice on Lake Michigan and flooded the Chicago markets with grain. ${ }^{4} \mathrm{~A}$ well-known event corner by Gould and Fisk in the gold market turned out to be a myth of American's past. ${ }^{5}$ Great manipulations took place until the twentieth century. ${ }^{6}$

Some operators made huge profits through the wheat squeeze. James A Pattern made a profit of up to two million dollars by raising the price of wheat per bushel from 1 dollar to 1.34 dollars. ${ }^{7}$ Jesse Livermore used strategic tactics in his manipulation. He used a New York newspaper, which had information of him cornering the July cotton market on its front page to inflate the value of his purchases, due to the fact that many investors quickly

\footnotetext{
${ }^{1}$ Van Smith, 'Preventing the Manipulation of Commodity Futures Markets: To Deliver or Not to Deliver?' (1981) 32 Hastings Law Journal 1569,1571

${ }^{2}$ Harold S. Irwin, Evolution of Futures Trading (Mimir 1954) 80.

${ }^{3}$ Thomas Applegate Hieronymus, Economics of Futures Trading, For Commercial and Personal Profit (2nd ed., Commodity Research Bureau 1977) 72-76.

${ }^{4}$ Leon T. Kendall, 'The Chicago Board of Trade and Federal Government: A Study of their Relationship, 1848 to 952' (unpublished dissertation, University of Indiana Business School, 26 May 1956) 11.

${ }^{5}$ Maury Klein, The Life and Legend of Jay Gould (Johns Hopkins University Press 1986) 99-115.

${ }^{6}$ Charles Henry Taylor, History of the Board of Trade of the City of Chicago (Chicago, R.O. Law 1917) 945-48, 963-69.

${ }^{7}$ Paul Sarnoff, Jesse Livermore: Speculator-King (Investors' Press 1985) 77.
} 
made up their minds to buy cotton in order to compete with him. Livermore had bought one hundred and twenty bales of cotton in 1908, thus making huge profits. ${ }^{8}$ On the other hand, Pattern also experienced great losses in the market. ${ }^{9}$

There were many other individuals who attempted to be manipulators such as Livermore. These included Crazy Harner, Benjamin Hutchinson and King Lack. ${ }^{10}$ They claimed in daily newspapers to be great heroes in terms of the wheat market. Their speculations led to great dislike and anger in the majority of the population. Nonetheless, the ongoing struggle to implement centralized controls over futures trading in the late 1800s and the turn of the century was unsuccessful. ${ }^{11}$

The effort to implement the Sherman Antitrust Act (that would have applied to trading in commodity futures) was one of various unsuccessful attempts. Others included the 'Hatch Act', which passed through the two houses but was unsuccessful in the Conference Committee. ${ }^{12}$ In addition, Theodore Roosevelt attempted to control 'dumpy' sales, which upset the market. He stated that there should be organized methods of preventing unsophisticated forms of betting in securities and merchandise. ${ }^{13}$ In this case 'unsophisticated forms' could be actions such as making sales above and beyond that which an individual actually owned, and restricting the market. Over thirty bills were presented as a reaction to this governmental message. None, however, were implemented. ${ }^{14}$

Although the proposed move against manipulation failed on the issue of intention, objective indicia of intent do exist. Some types of behaviour are likely to be associated with manipulative purposes in the proposed definition. A directing principle in identifying such behaviour is that rational investors usually attempt to buy as inexpensively as they can and sell as high as they are able to. Therefore, a dealer who buys for more, or sells for less, than that which was required to execute the transaction, is most likely to be acting for the purpose of manipulating price, rather than as an investor or opportunist. This type of uneconomic behaviour demonstrates itself in a number of practices, all of which are designed to emphasize the impact of price in any business, or chain of businesses. Practices of this nature are plainly detrimental, in the sense that they knock out of the market other competitors and, in the long term, reduce market diversity and options for the consumer.

Generally, traders achieve this cost impact by the manner in which they place their orders. As noted previously, all operations have some effect on price, and this is mainly true with large-scale businesses. Thus, any effort to buy a large quantity of a product will tend to force its price up. The rational dealer will seek to reduce the price impact of his own trades, since this will allow him to achieve the best value. When trades are effected in a manner that appears intended to heighten the price impact, manipulative intention may be suspected.

\section{The Definition of Market Manipulation}

No entirely satisfactory definition of market manipulation is yet available, in either the legal or economics literatures. ${ }^{15}$ However, numerous attempts at definitions related to regulatory, judicial and scholarly aspects exist. Cargill Inc v Hardin, ${ }^{16}$ a 1971 US case, provides a classic definition of market manipulation; any activity or scheme that has a deliberate influence on the price of a financial investment, leading to a varied price other than that which would have resulted in the absence of such an intervention. ${ }^{17}$ According to the Securities and Exchange Act of 1934, manipulation is: 'broadly defined as the effecting of changes in security prices by means of artificial stimuli, as opposed to the normal changes that occur in the free market subject only to the interplay of supply and demand'. ${ }^{18}$ According to the former president of the New York Cotton Exchange, A Marsh, manipulation is 'any and every operation or transaction or practice, the purpose of which is not primarily to

\footnotetext{
8 ibid 46-47.

9 Ibid.

${ }^{10}$ Charles Henry Taylor, History of the Board of Trade of the City of Chicago (Chicago, R.O. Law 1917) 503-04.

11 Leon T. Kendall, 'The Chicago Board of Trade and Federal Government: A Study of their Relationship, 1848 to 952 ' (unpublished dissertation, University of Indiana Business School, 26 May 1956) 105-06.

12 Board of Trade v United States, 246 US 231 (1918); United States v Patten, 226 US 525 (1913).

13 Cong Rec 1349 (31 January 1908).

14 Cong Rec 1403 (26 January 1909).

15 Emilios Avgouleas, The Mechanics And Regulation Of Market Abuse (Oxford University Press 2005); Rebecca Soderstrom, 'Regulation Market Manipulation: An Approach to Designing Regulatory Principles' (2011) Uppsala University: Working Paper 1.

16 Cargill Inc v Hardin, 452 F2d 1154 (1971).

https://doi.org/10.5694/j.1326-5377.1971.tb92765.x

17 Edmund C Stedman, The New York Stock Exchange (Greenwood Press1969) original work published 1905$) 445$.

18 Avgouleas (n 15).
} 
facilitate the movement of commodity at prices freely responsive to the forces of supply and demand; but on the contrary, is calculated to produce a price distortion of any kind in the market. ${ }^{19}$ All these definitions point to the fact that market participants are somehow fooled with the occurrence of market manipulation. ${ }^{20}$

The detailed definition of market manipulation affirms that it is characterized by four elements, namely:

i) the commission of a manipulative act or omission; ii) the intent to commit such an act or omission; iii) causation; iv) artificial pricing.

In economic terms, the concept involves the unfair transfer of market benefits and wealth from a large number of market players to a very small number of players through unfair means by the latter. ${ }^{21}$ Manipulation distorts the value, demand or supply of a financial instrument. ${ }^{22}$ The central aim of manipulation is distortion of the market price structure, leading to an artificial price of the financial instruments in the markets. Several of the factors that enhance market manipulation include rapid growth, involvement of inexperienced investors and lack of effective regulations. ${ }^{23}$ Some of the market manipulation strategies include wash sales (used to create the impression that certain securities are being traded more actively than is really the case), the use of matched orders (involved in a transaction related to the sale or purchase of the security with prior knowledge that a matching transaction would be entered by an associate at the same time, size or price), formation of pools (groups of people that come together with a goal of rigging the market), making an issue 'hot', warehousing, parking and boiler room operations (deceptive practices that involve the purchase of commodities whereby all or most of the investor's money is stolen). ${ }^{24}$

\section{The Dangers of Market Manipulation}

Perhaps the recent LIBOR scandal is the most appropriate place to start with anecdotal evidence of the dangers of artificially tinkering with the international market. Whilst not technically a manipulation of securities, the wide impacts of LIBOR rate-rigging have led to criminal convictions being mooted, a corporate blood bath and the financial health of many institutions being hit hard by the ripple effect of the self-serving practice. ${ }^{25}$ Furthermore, the reputational loss that occurs to some institutions can sometimes be the hardest damage to repair; distrust of an entire industry where the complexities and intricacies of operation are guarded from the layperson can be difficult to remedy. ${ }^{26}$

In a similar vein, market manipulation can have a widespread and damaging impact on the securities market. Market manipulation, where the market is effectively controlled by manipulative parties as opposed to the natural forces of the market, makes markets much less predictable, and this is a risk that investors are and will become increasingly aware of. ${ }^{27}$ Furthermore, the presence of this self-serving desire, coupled with a complete lack of transparency, has significant reputational impacts on a market, as its credibility is called into question by bona fide investors concerned about the security of their investments. ${ }^{28}$

Furthermore, market manipulation and the control it has can be uncomfortably felt from the manner in which natural market competition is distorted; giving such a false advantage or disadvantage can have a detrimental impact on the honest players within the market arena. ${ }^{29}$

Evidently, this type of practice, which is for the benefit of a minority at the expense of the majority, is financially,

19 ibid 106

${ }^{20}$ Soderstrom, (n15)

${ }^{21}$ Columbia Law Review Association, 'Illegality of Stock Market Manipulation' (1934) 34(3) Columbia Law Review 500-02. https://doi.org/10.2307/1115877

${ }^{22}$ Craig Pirrong, 'Energy Market Manipulation: Definition, Diagnosis, and Deterrence' (2010) 31(1) Energy Law Journal 1, 3-4.

${ }^{23}$ Landis Konecny, Stocks and Exchange (BoD 2012) 197.

${ }^{24}$ Daniel R Fischel and David J Ross, 'Should the Law Prohibit “Manipulation” in Financial Markets?' (1991) 105(2) Harvard Law Review 503, 507 https://doi.org/10.2307/1341697 ;Matthis Nelemans, 'Redefining Trade-Based Market Manipulation’ (2008) 42(4) Valparaiso University Law Review 1169, 1175; Craig Pirrong, 'Energy Market Manipulation: Definition, Diagnosis, and Deterrence' (2010) 31(1) Energy Law Journal 1,3-5.

${ }^{25}$ Justin O'Brien and Olivia Dixon, 'The Common Link in Failures and Scandals at the World's Leading Banks' (2013) 36 Seattle University Law Review 941, 941-43.

${ }^{26}$ ibid 942.

27 Stephen C Pirrong, The Economics, Law, and Public Policy of Market Power Manipulation (Kluwer Academic Publishers 1996) 124-25. https://doi.org/10.1007/978-1-4615-6259-7

${ }^{28}$ Satyajit Das, Extreme Money: Masters of the Universe and the Cult of Risk ( $1^{\text {st }}$ edn Financial Times Prentice Hall 2011$) 259$.

29 Joseph E Stiglitz and José Antonio Ocampo, Capital Market Liberalization and Development (Oxford University Press 2008) 299-300. 
socially and politically unattractive and can have incredibly damaging connotations all around; it is for this reason that several jurisdictions have enacted legislation in an attempt to try to stop such manipulative practices from being successful with both penal and deterring tools. A number of these enactments are considered below.

\section{The SEC's Anti-Manipulation Role after Dodd-Frank}

The credit default swap loophole that was opened up by Enron was closed, not by the passage of the Commodity Futures Trading Commission (CFTC) Reauthorization Act of 2008, but by the Dodd-Frank Wall Street Reform and the Consumer Protection Act of 2010. ${ }^{30}$ The Dodd-Frank Act began regulating the credit default swap market. A majority of swaps must now be handled through a regulated central counterpart that clarifies the exchange trade. ${ }^{31}$ Under the Dodd-Frank Act, swap dealers and major swap participants, but not end-users, can have margin and capital requirements imposed on them by regulators. ${ }^{32}$ Central counterpart, or clearing, houses must approve the standardized swaps. ${ }^{33}$ The Federal Trade Commission (FTC), and the Federal Regulatory Commission (FERC) set the stage for Dodd-Frank to grow the CFTC's anti-manipulation authority to a level that rivalled SEC. ${ }^{34}$ Dodd-Frank also combated abusive trading practices by authorizing the CFTC to deal with such matters. $^{35}$

In order to enable the SEC to regulate security swaps and security-based swap dealers, the Dodd-Frank Act underwent federal securities law amendments, and portion of the Enron loophole was closed. ${ }^{36}$ Under Dodd-Frank the CFTC was permitted oversee all swaps, other than security-based swaps regulated by the SEC, declaring shared jurisdiction over mixed swaps. ${ }^{37}$ Due to the additions to its anti-manipulation powers, the SEC was able to swap transactions that fell within its jurisdiction. ${ }^{38}$

To add to the SEC's increasing power, the Dodd-Frank Act authorized the SEC to adopt any rules that reasonably prevented security-based swaps from being traded fraudulently or harmed by deceptive or manipulative practices. ${ }^{39}$ This power was to be housed under section 9 of the 1934 Act, ${ }^{40}$ instead of section 10 (b) of the same statute. It is notable that the burden of proof under section 9 is greater than that described in section $10(\mathrm{~b}){ }^{41}$

Under this provision, in 2010 the SEC proposed rule 9j-1, which incorporates section 10(b) of the Securities Exchange Act of 1934, and the prohibitions in section 17(a) of the Securities Act of 1933, into the SEC's definition of fraud and manipulation. ${ }^{42}$ The proposed rule could apply to 'any person' and could encompass security-based swap dealers, those associated with counterparties, major security-based swap participants, and any other individuals the SEC deemed relevant. ${ }^{43}$ The SEC asserted that the proposed rule would be universally applied, and that end-users of security-based swaps would have no exemption. ${ }^{44}$ The rule sought to extend the power of prohibition to any exercise of right or obligation performance under a security-based swap. The nature of security-based swaps requires deliveries, ongoing payments, and collateral postings between the relevant parties. The SEC proposed to make 'explicit the liability of persons that engage in misconduct to trigger avoid or affect the value of such ongoing payments to deliveries. ${ }^{45}$

The difficulty, however, with the interaction between the legislation and the judiciary is that the latter has seen fit

\footnotetext{
${ }^{30}$ Samuel Rawson Gardiner, Report of Cases of The Star Chamber and High Commission (Camden Society1886) 43; Charlotte Twight, 'Dodd-Frank Accretion of Power, Illusion of Reform' (2015) 20(2) Independent Review 197, 197-198; Towns, Edolphus, 'On the Dodd-Frank Act' (2011) 1 Harvard Business Law Review

${ }^{31}$ II The Publication of the Selden Society, Select Cases Before The King Council in the Star Chamber (AD 1509-1544) (1908) 290.

32 State v Duluth Board of Trade, 121 NW 395, 403 (Minn 1909)

${ }^{33}$ Smith, A. An Inquiry into the Nature and Causes of the Wealth of Nations (1st ed., Great Books 19520 1776) 229 https://doi.org/10.1093/oseo/instance.00043218

${ }^{34}$ Hebert Hovenkamp, 'The Antitrust Movement and the Risk of Industrial Organizations' (1989) 68 Tex L Rev 105, 155.

${ }^{35}$ Section 747 of the Dodd-Frank Act.

${ }^{36}$ The Mogul Steamship Ltd v McGertor, Gow \& Co, 23 QBD 598 (1889).

${ }^{37}$ The King $v$ De Berenger, 105 Eng Rep 536 (1378-1865).

${ }^{38}$ William Laurence Saunders, The Colonial Records Of North Carolina (PM Hale State Printer 1886)185.

${ }^{39}$ Section 712 of the Dodd-Frank Act.

${ }^{40}$ Hovenkamp (n 34) 105, 155.

${ }^{41}$ Craig R. Enochs, 'Update on the Dodd-Frank Act' (2014) 36(2) Houston Journal of International Law 341, 348.

${ }^{42}$ Standard Oil Company of New Jersey v United States, 221 US 1, 55 (1910).

${ }^{43}$ Dan M. Berkovitz , 'Swaps provisions of Dodd-Frank Act: cost-benefit analysis and judicial review' (2014) 33(9) Banking \& Financial Services Policy Report 1, 12; Craig R. Enochs, 'Update on the Dodd-Frank Act' (2014) 36(2) Houston Journal of International Law 343.

${ }^{44}$ Federal Register, Vol 75, 68562.

${ }^{45}$ ibid.
} 
to forcefully apply or stretch legislation and the language of the law to unknown bounds. ${ }^{46}$ As Fischel has argued, the difficulty with the law has been that the judiciary has effectively shoe-horned secondary liability into the Securities Exchange Act of 1934 in circumstances where the language of the statute and the legislative history does not suggest that it was Congress's intention for such secondary liability to be imposed. ${ }^{47}$

Fraudulent conduct connected with security-based swaps which affect payments, deliveries, or cash flow values would also be controlled under this rule. An example of this is the obligation to trigger a counterparty to make a large deposit or offer up additional capital. A further example is the action taken to avoid triggering a larger payment or any further performance obligation related to a security-based swap. ${ }^{48}$

The SEC stated that prohibitions modelled according to rule 10b-5 would require proof of scienter in order to secure proof of a violation, while section 17(a)(2) and (a)3 of the Securities Act of 1933 requires equally strenuous conditions. ${ }^{49}$ The SEC states that under section 17(a), violations are only required to demonstrate negligence. ${ }^{50}$ The proposed rule differs in its language from the language used in rule $10 \mathrm{~b}-5$. The proposed rule includes 'manipulative' conduct, a term not in rule $10 \mathrm{~b}-5$ but found in section 10(b). ${ }^{51}$

\section{Market Manipulation in Islamic Law}

The word of manipulation has a specific Arabic meaning. Stock market manipulation is more than playing around; it is a premeditated crime with bad intention, in other words it is deviant behaviour in the stock market. However, in Islamic finance, the definitions, which are closely related to market manipulation, shall now be outlined.

1) Endangerment (Al-Taqreer):

(i) The exposure of person(s) to danger. ${ }^{52}$

(ii) Giving an exaggerated or deceptive account of an item's qualities, often portraying the item as being more valuable than it actually is, misleading another party into purchasing the item under false pretences. ${ }^{53}$

(iii) Encouraging or tempting parties by deception to perform some action. ${ }^{54}$

Endangering in dairy cattle by not milking them for long time before selling, in order to delude the buyer with the quantity of their milk is another example. ${ }^{55}$ It should be noted that there is a difference between endangerment and danger, where danger is defined as:

1) Something which has an unknown consequence. ${ }^{56}$

2) What was unknown between two allowances and the best of them is the most fairly one. ${ }^{57}$

There is, however, some similarity between danger and ignorance, and these concepts were differentiated by El Qrafi, who said:

The danger is the unknown whether it will happen or not, like selling the birds before caching it or selling fish in the water. While what is known has happened and was ignorance about its character, like selling anything he has in his bag, but he does not know what it is. Danger and unknown, every one of them is more general than other on one side and more specific on another side. ${ }^{58}$

There is a distinct difference between danger and endangerment, though danger refers to unknown consequences,

\footnotetext{
${ }^{46}$ Daniel Fischel, 'Secondary Liability Under Section 10(b) of the Securities Act 1934' (1981) 69 California Law Review 80, 111. https://doi.org/10.2307/3480207

47 ibid.

${ }^{48}$ Federal Register, Vol 75, 68563.

${ }^{49}$ Securities Act of 1933, s17(a)2 \& s17(a)3.

https://doi.org/10.1136/bmj.2.3783.S17

${ }^{50}$ ibid.

51 ibid.

52 Jamaluddin Muhammad Ibn Manzūur, Lisān al- 'Arab (Dar Sadir 1997); Mahammed El Razi, Mokhtar El Sahah (Maktabt 1986) 471-472.

53 'Provisions of Legitimate Transactions' (Dar Sadir1997) 377-380; Nazih Hamada, Mujam al-Mustalahat al-Maliyah wa al-Iqtisadiyah $f i$ Lughah al-Fuqaha ( Dar al-Qalam 2008) 119.

${ }_{54}$ Mohammed El Zarqa, Al Madkhal Alfiqhi Alaam, (Dar Al-Qalam1998) Pt 1, 379.

${ }^{55}$ Mohammed El Zarqa, Al Madkhal Alfiqhi Alaam (Dar Al-Qalam1998) Pt 1, 463-464.

${ }^{56}$ ibid.

${ }^{57}$ Ali El Mwardi, El-Hawi Alkabeer, (Dar Alkutub Alelmyah 1994) Pt 5, 325.

58 Ahmed Alsanhaji El Qrafi, Anwar Albroq Fee Anwa Alforoq “El Froq" (Dar Alsalam 2001) Pt 3,365.
} 
while endangerment refers to sayings or actions, which trick someone; hence, danger involves risk and endangerment involves trickery, which leads to risk. From the definition of endangerment at the start of this section, and its closely related terms, it can be reasonably deduced that endangerment is one form of 'market manipulation' since the manipulation of others is typically done through trickery, fraud, deceit and illusion.

About fraud, Ibn Qudama says: 'If one, with the intention of concealing a defect, hides it from the buyer instead of declaring it or covers it to delude the buyer into thinking that there is no defect, then they have committed fraud, meaning an injustice towards the buyer. ${ }^{59}$ And it has been said that 'fraud can be committed in two ways: the first way is by hiding a defect and the other is by adding makeup to raise the price. From previous definitions it can be deduced that fraud is another form of market manipulation. ${ }^{60}$

Similarly, trickery is when a man pursues illegal ways to achieve his purpose in such a manner that nobody detects his deceit without some semblance of intelligence and insight. ${ }^{61}$ And this thing does exist in manipulation by showing some things different from what is hiding in order to reach a specific purpose. ${ }^{62}$ A gyp utilizes both trickery and endangerment to induce an individual to buy a commodity, resulting in the selling party profiting from the buyer. A gyp is not just restricted to this definition and can also involve danger (where the commodity was sold by dishonest advertisement) and, thus, the gyp may be considered a specialist form of manipulation. ${ }^{63}$ So the manipulator is one who solicits and stimulates other traders to make them act thinking that they can make profit, whereas in reality they will lose. Should this be considered as just a play, or is it a sort of cheating and betraying?

Theoretically we need to differentiate between stock exchange traders, investors, speculators and manipulators, knowing that the investor is the one who owns the currency as an asset to gain profit from it, like a production asset generating profit time passes. Whereas the speculator is the one who uses the currency as a commodity, wishing its price to increase to get rid of it and make profit, he buys it with the intention to resell it and make profit.

Based on this we can guess that the currency might remain in the possession of the investor much longer than in the possession of the speculator. That is to say, both investor and speculator are supposed to have enough reliable information about the currency they are dealing with. Like a merchant who is keen to choose his commodities, we can say the speculator is truly a merchant in the right meaning of the world, the market is his shop and the stock his commodities. That is why if he does not rely on genuine information and plays just by chance then he is merely gambling. Whereas the manipulator does not rely for his decisions on information gained nor on chance, but he creates the circumstances by giving a false impression to stimulate other traders and let them act according to wrong information, then he jumps on the market buying or selling, making profit without care for others who lose, not only that but he pushes them to lose heavily so he can make a bigger profit. Investors in the stock exchange are very few, but the expert speculators are more, the gamblers are even more, whereas manipulators as a matter of number they are very few, but they have a high influence in stock market. ${ }^{64}$

\section{Financial Market in Islam}

Islamic Law has approved all sorts of markets, observing their necessity for individuals and societies who cannot dispense with them, stating the need to respect all rules and regulations in any market. Islamic law accords much importance to markets, creating rules and regulations to prevent violations and harmful behaviours such as cheating, holding monopoly, fraud, stimulation, etc. It made one of the priorities of a ruler to control markets, to see what happens in them and punish any trouble makers. ${ }^{65}$

When the Prophet (peace be upon him) migrated to Medina he noticed that the market was dominated by Jews, who were abusing the Arab people living there, so one of the first decisions he made was to create a market for the Muslim people in Medina to free them from being abused. But he did not create this market without providing guidance, he set out rules and one day announced publicly: 'Who cheats is not one of us'; cheating

\footnotetext{
${ }_{59}$ Mohammed Ibn Qudama Al-Maqdissi, El Moghani (Dar Alam Alkutub 1997) Pt 6, 234.

${ }^{60}$ Mohammed El Baali, Almuttala Ala Aboab Alfiqh (Almaktab Alislami 1988) Pt 11,236.

${ }^{61}$ Ibn Qayyim al-Jawziyyah, I'laam ul Muwaqqi'een 'an Rabb il 'Aalameen (Dar Ibn Aljawziyy, 2008) Pt 3,309.

${ }_{62}$ Mohammed Ibn Qudama Al-Maqdissi, El Moghani (Dar Alam Alkutub 1997) Pt 6, 304.

63 ibid.

${ }^{64}$ Obaidullah Ibn Battah Al-Akbaree, Prohibition of Fraud (Ar-Risaalah Company 1996) 112-122.

${ }^{65}$ Mubarak Alsulyman, Ahkam Altaamul Fe Alaswaq Almalyah (Knoz Ishbylah 2005) Pt 1,15-18; M Fahim Khan and Mario Porzio, Islamic Banking And Finance In The European Union (Edward Elgar 2010) 11-17; Asyraf Wajdi Dusuki., Islamic Financial System (International Shariah Research Academy for Islamic Finance 2011).
} 
was seen as a big sin that would remove cheater from of the Muslim community. He also appointed some of his great companions to control and check regularly the attitudes and behaviours of people in the market.

His successors did the same; we can find many stories of the second Khalifa (Omar ibn Alkhattab) who was very stringent with manipulators and monopolists, and he was very interested in establishing a stable market, obliging merchants not to increase nor decrease the price of some goods, although the decrease would be good for customers but still Omar refused this because it might lead to disputes between the merchants and might affect the stability of the whole market. ${ }^{66}$

Islamic law paid great attention to business and markets and protecting them from any sort of misconducts and manipulations. The scholar Yahia ibn Omar said: 'any governor intending to establish justice within his citizens, has to control the markets and appoint the most trusted people to keep an eye on it. While talking about these people the trouble makers in the market scholar Ibn Alkiyam said: 'these people are spoiling the interest of the nation, the harm they create is general so the governor must harass and lock them and punish them continuously because their harm affects every body. As such we can see how Islamic law stood against anyone trying to behave in a market in a way that might harm others or create confusion in the market, leading it to lose the purpose of its creation. As discussed we saw how manipulation in the stock market is a calamity and a global harm that should oblige rulers to strongly punish for it in the appropriate way.

\section{Jurisprudential Legislation for Manipulation in the Financial Markets}

Regardless of the type of manipulation, in itself it is illegal in the financial market and manifests mainly as verbal deception similar to those deceptions discussed above, i.e. fraud, gyps, cheating, concealment of defects, since all of these behaviours lead to a corruption of information in financial papers and, hence, a real loss for traders. $^{67}$

There is an abundance of evidence in the Holy Qur'an and the Sunnah pointing to the justification of forbidding cheating and fraud. For example, Allah said: 'O' you believers, do not consume your wealth among yourselves in falsehood, except where you trade in mutual agreement. And do not kill yourselves. Allah is the most merciful to you. ${ }^{68}$

Thus, manipulation and deception in financial transactions is forbidden. The difference between the market and the financial market is that the prices in the former are defined by unilateral outbidding (eg a seller and a group of buyers in an auction) or unilateral bidding (eg one buyer and a group of sellers in a government bid), while the control on prices in the financial markets is decided through auctions and outbidding, where sellers compete to decrease prices and buyers compete to raise prices. Deception in the financial market occurs on both sides, by the sellers and the buyers. Vendors try pushing price to decrease and buyers do the opposite.

Qais ibn Saad ibn Ebada said, 'The Prophet said, 'the deceiving is in the hell' [the text states the deceiving as an action is in hell; but it means the deceiver]. ${ }^{, 69}$

Cheating leads to hell and, accordingly, it attracts a harsh punishment, which seeks to deter such behaviour. Omar's son said, 'The Prophet forbids gyp. ${ }^{70}$ Gyp is detrimental to any contractor since cheating can artificially raise the price of a product; therefore, fraudulence, cheating and concealment in the financial market are forbidden. ${ }^{71}$

\section{The Effects of Manipulation on the Financial Market}

There are a number of legal effects of prohibition of manipulation on the financial markets. That is why such attitudes and behaviour are forbidden and invalidate such contracts and request compensation. Manipulation in the financial markets is included in the rules on cheating and actual and verbal deceit. Jurists agreed that the rules consider gyp and informal money exchanges as verbal deception, while fraudulence is deemed 'actual deception'. An overview of jurists' decisions will now be provided.

Most scholars say that exchanging money is forbidden but there are different views about its effects on the validity of a contract. The general consensus among scholars seems to be that a contract is valid but unnecessary.

\footnotetext{
${ }^{66}$ Mubarak Alsulyman, Ahkam Altaamul Fe Alaswaq Almalyah (Knoz Ishbylah, 2005) Pt 1, 15.

${ }^{67}$ Mohammed El-El-Sehibani and Abdulah El-Omrani, Rules of Electronic Negotiation in Stock Markets and Views on its Islamic Evidences, Securities Markets and Bourses, Prospects and Challenges Dubai, 2007) Pt 2, 25.

${ }^{68}$ Holy Qur'an, Surat Al-nisa (4) Ayah 29.

${ }^{69}$ Narrated by Muslim (Hadith number 102), Mohammed al-Shawkaani, Neil al-Awtaar, Arabic edition (Dar al-Jeel 1973) Pt 3, 240.

${ }^{70}$ Narrated by El-Bukhari (Hadith number 2142), Muslim (Hadith number 1516).

${ }^{71}$ Abdulah Alsalmi, Fraud and its Impact on Contracts, (Arabic edition Knoz Ishbylah 2004) Pt 1,103.
} 
Ibn Taymiya accredited this view to most of the jurists. ${ }^{72}$

A number of scholars have said that:

(i) Nullifying contracts and cancelling transactions within a certain definite time period and repurchasing is legal. ${ }^{73}$

(ii) The validity of the contract and invalidity of the choice and claim back the extra value by the ruler and may levy a fine proportional to his cheating and deceiving. ${ }^{74}$

\section{Islamic Ruling on Manipulations}

We saw earlier the issue of intercepting merchants, city men to offering to sell goods of a countryside man , Najash and how they can harm people. I will discuss here different opinions of scholars on the effect of Najash selling contracts because Najashis the closest form of trading to the manipulations in stock market; what it contains is the increase of the prices and stimulating buyers to buy due to higher unreal bidding offers, and this is what is happening in stock markets nowadays.

Imam Tirmidhi (may Allah grant him mercy) said, 'Najash happens if a man come to a dealer and offer him a high price just with the intention to make other buyers stimulated (not with intention to buy himself), and this is a sort of cunning and guile. ${ }^{75}$ Imam Tirmidhis' description is as if he is talking about what is happening nowadays in stock market. Scholars have three different opinions about contracts with the existence of Najash: First Opinion The sale is true but the buyer has a right to choose to keep or nullify it. Second Opinion The deal is void, and this is an opinion of Imam Ahmed and some Hadith scholars. ${ }^{76}$ Third Opinion The deal is correct and obligatory, and there is no way to terminate the contract without the agreement of both parties. ${ }^{77}$

It is an evidentiary fact that the option addressed first consists of all the evidences and hence recommended. However, the option third lacks to address the rights of the victims therefore, is on the weakest side. Based on the above, the dealing made by the victim of any of the above methods, his trading in the stock market is correct but still preserves the right to keep or nullify the deal,. Usually, he will choose to nullify, especially if the loss is heavy.

The penalties and fines made against some manipulators who violated the Saudi stock market system contained an obligation for the violating trader to pay back all that has been gained through these violations, ${ }^{78}$ but did not state whether the victims would be repaid whenever they are determined by working out the number of transactions related to the shares in question.

Other systems have proposed a different way of punishment, by cancelling all transactions related to that particular share and all implications from the beginning of the violation to the end ${ }^{79}$ It is suggest that this is an annulment of the contract and I believe this is a wise choice, though most dealers like the annulments due to their heavy losses.

Nowadays, catching any dealings related to any share during any given period of time may be easy to be easily facilitated, to a situation back to its original place before the dealers started manipulating. Of course it does not mean not punishing the violators to deter them, and cancelling all transactions by the violators.

\section{Al Hisbah}

The Hisbah (A Regulatory Agency):

It is important at the outset of this subsection to remind us of the nature of the institution of Hisbah and its historical role and functions in the Muslim market. It may be one of the most deep-rooted institutions of market regulation, not only in the Islamic history, but also in the history of mankind at large.

It is irrelevant and perhaps futile to argue whether Hisbah is an Islamically created institution or it existed before

\footnotetext{
72 Ahmed Ibn-Taymiya, Majmu Alfatawi (Arabic edition Dar al Wafa and Dar Ibn Hazm) Pt 28, 102.

${ }^{73}$ Saleh Alsultan, Shares and their Provisions and Implications (Arabic edition Dar Ibn Aljozi, 2006).

${ }^{74}$ Abdullah El-Sulmi, 'The Rule of Speculation in Financial Markets' Seminar on 'Speculation and Manipulation in the Financial Markets' (Islamic World League, Islamic International Foundation for Economics \& Finance) 102.

75 Imam al-Tirmidhi, Mentioned after Hadith 1304, For more information see: Mohammed Alqahtani, `Alnajash (2006) 29 Al-Adl Journal Ministry of Justice, 105-106.

${ }^{76}$ Ali Alasqalani Ibnhajar, Fath ul-Bari fi Sharh Sahih al-Bukhari (Arabic edition Dar Al-Riyadh 2001) Pt 4,355.

77 ibid Pt 5,239.

${ }^{78}$ Al Barbary Saleh, 'Speculation and Market Manipulation' (2007).

79 ibid.
} 
Islam. What matters really is that it is an institution that existed since the time of the prophet (pbuh) and it continued since then, with an important market role, to the extent that it has become a powerful institution that was intrinsically attached to the Muslim markets throughout the economic history of Islam. It is reported that the prophet Muhammad (pbuh) was the first ruler in the Islamic history that practiced the Hisbah on the market. And it was assigned to outstanding and Shari'ah-knowledgeable persons ever since the death of the prophet (pbuh). ${ }^{80}$

The Muhtasib (ombudsman) is surrounded by who can enforce her/his decisions using the law enforcement agencies. The word is itself obtained from Hisab (account/accountability), and the institution of Hisbah, was allocated quite a lot of market functions in the Islamic history and jurisprudence. These following are some of the defined functions including:

1. Quality control: In this function, different products were passed through quality checks and supervision to guarantee a quality standard that is preferred by the society.

2. Shari'ah control: This function incorporated the supervision of the market players from the perspective of the compatibility of their contracts with the Shari'ah, that no Riba contracts are completed, neither dishonesty nor scam, among others are experienced.

3. Moral sieving: In this function, all actors in the market were involved in their transactions while monitoring the moral and ethical principles of the Shari'ah. These comprise honesty in transaction and statement of all the features of products, beginners are not handled dishonorably, animals are not over-loaded or starved, among others.

4. Environmental control: This function consists of all those transacting and do not surpass their individual domain of practice. For example, traders do not display goods and merchandise in the street outside their individual shops, thereby trespassing on the right of buyers and bystanders to the entire street. In addition, craftsmen do not generate fumes or other units that may cause harm to bystanders or neighbors; noise-generating craftsmen have retails far from suburban regions and other businesses, among others, etc. ${ }^{81}$

5. Health control: This function was accorded to the Hisbah institution in the Islamic market. For example, it is expected that all goods should be protected from insects, such that their production is conducted under healthy circumstances, without harmful or foul ingredients are added by the manufacturer. The function helps in ensuring that manufacturers of bread, meat, as well as other ready food items observe all guideless of hygiene to the level that they were compel to engage an employee to mix the air incessantly to derive away flies and other insects. This helps in washing the products with soap (Muslims designed soap), to protect their nose, mouths, alongside all their hair when handling dough and the fresh bread, among other related products. Actually, it is found in the conventional books on Hisbah a comprehensive description of health, hygiene rules and recommended methods of inspection, such as impromptu visits.

6. The arbitration function: This function was designed to support the Hisbah institution to help in managing market disputes between employees and employers along with disputes between vendors and consumers and among the merchants. In this context, the Hisbah characterizes an agency that provides quick and instantaneous mediation to resolve disputes before they get to the court. Whenever the instant the two parties admit the arbitration of the Muhtasib, any of the Muhtasib subordinates or occasionally a committee created by the Muhtasib, the disagreement is typically resolved immediately without waiting for court proceedings. ${ }^{82}$

7. Anti-monopoly functions and pricing: This policy was assigned to the Hisbah institution in order to see to ensure that no monopoly is experienced within the market. The type of monopolies cited in the books of Hisbah in which the Muhtasib has to apply incorporate an implicit agreement between manufacturers to increase the prices of their services or products. It incorporates the presence of one manufacturer or seller of a product in case he/she hoards or keeps a commodity so as to minimize the market supply. In case a product is essentially manufactured by one single producer, then the Hisbah institution must impose proper pricing as a regulator, as claimed by IbnTaymiyyah et al. Therefore, this function incorporates pricing in case it becomes the only means of eradicating monopolistic activities.

8. Market supervision: The supervision over the sustained provision of public utility services within the market and society is essential within the Hisbah institution. It was assigned the task of ensuring that the public utilities are conducted in a proper manner. These consist of roads, bridges, streetlights, water fountains for

80 ibid.

81 Al Mubarak, Muhammad, Al dawlah wa Nizam al Hisbah Inda ibn Taymiyyah, (Dar al Fikr 1967).

82 ibid. 
homes and Mosques, public restrooms, drainage, sewage, among others. In case any of these public services is breached or impacted by tear and wear or naturally disasters, the Hisbah institution chips in to oversee repair and maintenance. In case there are no financial resources allocated in the treasury of the local government, aid from the center is pursued or taxes are imposed on the affluent for repair and maintenance of public services. $^{83}$

The institution of Hisbah had an inheritance in all Islamic nations and big cities, which was established in the Muslim community when Europe was drowning in ignorance and savagery. The establishment of Hisbah, once rejuvenated, characterizes a semi-governmental corporation that controls a number of elements of market regulations particularly those that do not fall within the category of the macro policies. It can be charged with all or a number of the described functions of which there is a rich historical experience. The other tools of direct regulations of the market and the macro-lend regulations still exist for control of other functions as will be described in the subsequent subsections of this analysis. ${ }^{84}$

\section{Overview}

The securities market is constantly in flux, with frequent new developments made in substance and procedure. As such, the law is posed with the difficulty of creating a standardized definition which is sufficiently specific as this specificity would act as a limitation, restricting the definition from applying to new scenarios. This concern becomes more important when it comes to formulating exact definitions for market manipulation and insider trading. This is felt when observing the law on market manipulation and insider trading incorporated by the legal regimes discussed here (US law, Islamic law). The US law on the matter contained primarily in section 9 of the Securities and Exchange Act 1934 fails to give a definition of market manipulation or insider trading; rather it gives generalized circumstances (drafted very broadly) which would constitute Market Manipulation or Insider Trading. ${ }^{85}$ The US operate dual (civil and criminal) regimes in dealing with Market Manipulation and Insider Trading. In US law both civil and criminal prosecutions may be brought under section 9 of the Securities and Exchange Act $1934 .{ }^{86}$ Furthermore in the US civil proceedings are brought by the Securities and Exchange Commission whereas criminal cases are prosecuted by the Department of Justice.

\section{Criminal Regime}

As a general rule the threshold to win a civil case is the 'balance of probabilities' (also known in the US as a 'preponderance of evidence') and a criminal case 'beyond reasonable doubt'. It requires a substantially higher standard of proof to prove a criminal case than it takes to prove a civil one. This is the reason that many cases lose criminal trials but win civil ones. In the US the emphasis has primarily also been on bringing civil proceedings by the Securities and Exchange Commission.

In the US the Securities and Exchange Commission only brings civil proceedings and any cases it feels warrant criminal prosecution it refers to the Department of Justice. Under dual regimes of this sort the same law or offence is used for both civil and criminal cases; for example, in the OJ Simpson case the state first brought criminal proceedings for murder, but once the case was lost another proceeding in civil law was brought for wrongful death, this second proceeding proving successful. The difference however would be the requirements and standard to be fulfilled in order to satisfy both regimes. In the US the primary law on market manipulation and insider trading is contained in the Securities and Exchange Act 1934 which is used for civil proceedings. However under section 32(a) of the Securities and Exchange Act 1934 any individual who violates any provision: ${ }^{87}$

shall upon conviction be fined not more than $\$ 5,000,000$, or imprisoned not more than 20 years, or both, except that when such person is a person other than a natural person, a fine not exceeding $\$ 25,000,000$ may be imposed; but no person shall be subject to imprisonment under this section for the violation of any rule or regulation if he proves that he had no knowledge of such rule or regulation.

Thus section 32(a) gives the Securities and Exchange Act 1934 full applicability in criminal cases as well as specifying the test to be used and the penalties to be given. ${ }^{88}$

\footnotetext{
${ }^{83}$ Ibn Taymiyyah, Ahmad, Al Hisbah fi al Islam, (edited by Muhammad al Mubarak, Dar al Kutub Al Arabiyyah1967).

${ }^{84}$ ibid; Ziadeh, Nichola, Al Hisbah wa al Muhtasib fi al Islam, (old texts collected and edited with an introduction, Catholic Press 1962); Al Shirazi, Nihayat al Rutbah fi Talab al Hisbah, (edited by al Arini, Lajnat al Ta'lif wa al Tarjamah wa al Nashr Publishers, Cairo1946)

${ }^{85}$ Securities and Exchange Act 1934, s9.

${ }^{86}$ Securities and Exchange Act 1934, s9.

${ }^{87}$ Securities and Exchange Act 1934, s32(a). https://doi.org/10.2307/1280499

88 ibid.
} 
The Bureau of Investigation and Public Prosecution, like the US Department of Justice, would handle criminal proceedings.

In sixth-century Arabia, state enforcement of crime was primarily done by the executive. In Islamic law there are three primary classifications of offences Hadd, Tazir and Qisas ${ }^{89}$ Hadd offences are the offences that have a fixed penalty stated in the Qur'an, these are usually more serious offences like theft, consuming intoxicants, etc. ${ }^{90}$ Tazir offences are punishable offences but the Holy Qur'an does not expressly provide these punishment, this puts these punishments at the discretion of the head of state. ${ }^{91}$ Qisas offences are offences against the person such as murder, manslaughter and battery. ${ }^{92}$ Applying these concepts one can see that Islamic law too maintains a dualistic regime with civil offences being brought privately by individuals in the form of claims in front of the Qadi and criminal offences being punished by the Caliph (or in his name by those designated). Market manipulation and insider trading are offences involving dishonesty, in which property (money) belonging to another is fraudulently appropriated. While the act sounds similar to theft, it is far more sophisticated, lacking any of the physical appropriation elements. It is more likely that under Islamic law the offences of Market abuse would be categorized as Tazir, which gives the Caliph (or head of state) the discretion to decide the penalty.

\section{Conclusion}

US law essentially focuses on the registration process as well as the civil remedies. Among the ways in which the law seeks to limit abusive practices is through the requirement for issuers of securities as well as other collateral parties involved in the sale process to dutifully disclose all the material information that will in turn enable the investors to make an informed decision of whether or not to buy the securities, after scrutinizing the information that is truthfully availed to them. A regime of administrative controls, supplemented by criminal and civil liabilities is further utilized to ensure that the identified obligations are fully complied with.

Both the common law and statutory law offer shareholders a legal right to information about a company's affairs. However, this is a limited right, and is only available to shareholders. The same right is not given to an investor. The seller is required by law not to utter falsehoods or otherwise mislead with no obligation to speak. Nonetheless, statutory developments in this field were also noted to virtually render the principle of caveat emptor irrelevant.

An Islamic economy achieves a balance between the profit sector (represented by the market) and the non-profit sector (represented by social institutions); finding this balance helps to contain the negative effects of the market. ${ }^{93}$ In a scientific study conducted by a sector of the economic world, it was confirmed that the profit sector should be maintained to support the non-profit sector and encourage that, which will bring stability to the economic market.

Each of legal regimes discussed in this article recognize the threat Market Manipulation and Insider Trading pose. As such, each regime has attempted to develop its own tools, in the form of laws and regulatory practices to combat it. Although some differences are seen between the legal regimes (US and Islamic law), they have all attempted to use modern knowledge of market abuse to formulate their laws. So while their laws may differ in form and procedure, they are similar in substance. In addition, the distinction between Islamic law and other legal systems lies in two things:

First: Islamic law encourage people to learn trading and its' methods, so then they can be aware of what they are doing, and no doubt this will reduce the number of violations in trading. Second: Islamic law focuses on trading values and requests all dealers to be honest and promote honestly, and warns against lying and cheating, marking them as sins. And this issue in particular does not exist in other law systems, and of course this is a lacuna that the manipulators use to create problems.

\section{Copyrights}

Copyright for this article is retained by the author(s), with first publication rights granted to the journal.

This is an open-access article distributed under the terms and conditions of the Creative Commons Attribution license (http://creativecommons.org/licenses/by/4.0/).

${ }^{89}$ Global Islamic Finance, 'MajAllah al-akhkam al-'adiliyya'.
www.global-islamicfinance.com/2009/07/al-majAllah-al-ahkam-al-adaliyyah.html
90 ibid.
${ }^{91}$ ibid.
92 ibid.
93 ibid.

